\title{
Evaluation of physical educators' knowledge about epilepsy
}

\author{
Rodrigo Luiz Vancini', Claudio Andre Barbosa de Lira ${ }^{1,2}$, \\ Sergio Gomes da Silva', Fúlvio Alexandre Scorza ${ }^{3}$, Antonio Carlos da Silva', \\ Douglas Vieira ${ }^{3}$, Esper Abrão Cavalheiro ${ }^{3}$, Ricardo Mario Arida'
}

\begin{abstract}
People with epilepsy suffer from a considerable lack of physical activity. In addition, an important problem of epilepsy management is the lack of qualified professionals. In this study we present data from a survey which aimed to assess physical educators' general knowledge about epilepsy. One hundred and thirty four physical educators of both sexes answered a questionnaire. Sixty percent of the professionals believe that a seizure is an abnormal electrical discharge of the brain, 13\% that epilepsy is a cerebral chronic disease that can not be cured or controlled, $84 \%$ that people having convulsions will not necessarily present epilepsy and $5 \%$ that people with epilepsy have difficulties of learning. Questions concerned previous professional experience with epilepsy showed that $61 \%$ have seen a seizure and $53 \%$ have access to some information about epilepsy. Thus, $28 \%$ of professionals have a friend or relative with epilepsy, 14\% have a student with epilepsy, and 29\% helped someone during seizures. Our findings reveal a lack of physical educators' appropriate knowledge about epilepsy. Improvement of this might contribute to the improvement of epilepsy care/management. Key words: physical activity, physical education, epilepsy, knowledge.
\end{abstract}

\section{Avaliação do conhecimento de professores de educação física sobre epilepsia}

\section{RESUMO}

Pessoas com epilepsia apresentam baixa participação em atividades físicas. Um importante problema nos cuidados da epilepsia é a falta de profissionais qualificados. Neste estudo apresentamos dados de uma pesquisa para avaliar o conhecimento de professores de educação física sobre a epilepsia. Um questionário foi respondido por 134 educadores físicos de ambos os sexos. Sessenta por cento dos profissionais acreditam que a crise epilética é uma descarga elétrica anormal do cérebro, 13\% que a epilepsia é uma doença crônica cerebral que não pode ser curada ou controlada, $84 \%$ que pessoas que têm convulsões não necessariamente apresentam epilepsia e 5\% que pessoas com epilepsia têm dificuldade de aprendizado. Em relação à experiência prévia do profissional, 61\% presenciaram uma crise epilética e 53\% tiveram acesso a alguma informação sobre epilepsia. Além disso, 28\% dos profissionais possuíam amigo ou parente com epilepsia, $14 \%$ tinham um aluno com epilepsia e $29 \%$ já tinham socorrido alguém durante uma crise. Nossos achados revelam uma falta de conhecimento apropriado dos profissionais da área

\section{Correspondence}

Ricardo Mario Arida

Universidade Federal de

São Paulo (UNIFESP)

Rua Botucatu $862 / 5^{\circ}$ andar

04023-900 São Paulo SP - Brasil

E-mail: arida.nexp@epm.br

\section{Support}

Research supported by CNPq, FAPESP, CAPES, INNT and CInAPCe (Brazil)

Received 28 July 2009

Received in final form 14 December 2009

Accepted 23 December 2009

de educação física sobre a epilepsia. A melhora desse conhecimento pode contribuir para um adequado tratamento e cuidado da pessoa com epilepsia.

Palavras-chave: atividade física, educação física, epilepsia, conhecimento.

The epilepsies are the most common serious neurological condition, affecting cognitive, emotional, and behavioral con- ditions, ability to work, social functioning, family stability and self-esteem of the patient. They are characterized by spontane- 
ous recurrent seizures, caused by focal or generalized paroxysmal changes in neurological functions triggered by abnormal electrical activity in the brain ${ }^{1}$.

Physical exercise has been recommended as an important tool to reduce risk of cardiovascular and endocrine disease, and improve bone and muscle conditioning $^{2}$. In this regard, people with epilepsy should have the same benefits from an adapted physical training program as healthy persons: increased maximal aerobic capacity, increased work capacity, reduced heart rate on submaximal standardized work level, weight reduction with reduced body fat, increase self-esteem, and an antidepressant effect ${ }^{3,4}$.

There are several data demonstrating that people with epilepsy would receive similar benefits from physical activity. For instance, Roth et al. ${ }^{5}$, which examined physical exercise, stressful life experiences, and depression in adults with epilepsy, found that active subjects had significantly lower levels of depression than inactive subjects, as well as better psychosocial adjustment. Similarly, Nakken et al. ${ }^{3}$ also noted that after a 4-week exercise program, individuals with epilepsy had an improved mental state and became more sociable. However, it has been observed that people with epilepsy suffer from a considerable lack of physical fitness that might have an impact on their general health and quality of life. People with epilepsy present significant deficits in aerobic endurance, muscle strength endurance and physical flexibility ${ }^{6}$. For instance, Nakken et al. ${ }^{3}$ found considerably lower maximum oxygen uptake in people with epilepsy than average population. These findings are also observed in children with epilepsy. A study conducted by Wong and Wirrell ${ }^{7}$ demonstrated that teens with epilepsy were less physically active than their sibling controls. Despite medical recommendations toward encouraging rather than restricting participation, the stigma remains and persons with epilepsy continue to be less active than the general population. In these lines, several studies have shown a low degree of participation in physical activities among persons with epilepsy,8-10. This reluctance of patients and physicians is due in part to fear of injuries and in part to fear that exercise will cause seizures $^{8}$. At the same time as restriction and overprotection are put into action, clinical ${ }^{3,9,11,12}$ and experimental studies ${ }^{13-15}$ have shown positive effects of exercise in epilepsy. For instance, most experiments on brain electrical activity have shown that abnormal discharges disappear in most patients during physical activity but return at rest ${ }^{11,16}$. It has been also observed that fewer seizures occur during both mental and physical activity compared with periods of rest ${ }^{18,19}$. The increased vigilance and attention involved in exercise could explain the reduction in the number of seizures ${ }^{16}$. In animal studies, a reduction of seizure frequency was observed after an aerobic physical training ${ }^{14,19}$. In this line, all the positive effects are reached since the physical exercise is well-guided and accompanied by specialized professional ${ }^{21}$. The literature suggests that once the patient's seizures are well controlled they should participate in sports and physical activities. An important problem of epilepsy management is the lack of qualified professionals. In countries where specialist professionals are not commonly observed, an evaluation of knowledge in epilepsy could help to additional information for physical educators to contribute for the improvement of epilepsy care/management.

As physical exercise is usually prescribed and accompanied by a specialized physical educators, we aim to evaluate the knowledge of professional's physical education toward epilepsy in order to give them more effective support concerning safety precautions and understanding of positive effect of exercise on epilepsy.

\section{METHOD}

Subjects with academic degree in Physical Education, that lived in São Paulo City, Brazil, were invited to participate in this study. A self-administered questionnaire was designed to verify the knowledge about epilepsy and physical activity. The inclusion criterion to participate in the study was: professional with graduate degree in Physical Education. All subjects signed an informed consent document. All procedures involved in this study were approved by the University Ethic Committee.

The subjects answered a 16 -item questionnaire with 15 simple close-end type response scales (Table 1 and 2) and one multiple choice question. Questions concerned: [A] general knowledge about epilepsy (10 questions) and [B] previous professional experience related to epilepsy (5 questions). The questionnaire was answered by 134 subjects (102 males and 32 females; mean age, 27.2 years; range $20-46$ years). From all subjects $14.9 \%(\mathrm{n}=20)$ were postgraduate and $85.1 \%(\mathrm{n}=114)$ had only academic degree. Briefly, $57.4 \%$ ( $n=77$ ) of them had professional experience with healthy subjects, $30.0 \%(\mathrm{n}=40)$ with high-level sport, $10.4 \%$ $(\mathrm{n}=14)$ with scholar physical education, $2.2 \%(\mathrm{n}=3)$ with scientific research and 9.0\% $(n=12)$ did not answer. A descriptive statistic analysis was used through computer software.

\section{RESULTS}

The first part of the questionnaire was designed to assess the general physical educators' knowledge about epilepsy. One hundred percent $(n=134)$ of the subjects interviewed had already heard about epilepsy and $98.5 \%$ believe that epilepsy is not an infectious disease. Thirteen percent $(n=18)$ believe that epilepsy is a cerebral chronic disease that can not be cured or controlled. Sixty percent $(\mathrm{n}=81)$ believe that a seizure is an abnormal electrical discharge of the brain. The majority of them $(84.3 \%$, 
Table 1. General knowledge about epilepsy.

\begin{tabular}{|c|c|c|c|}
\hline Question & $\begin{array}{c}\text { Yes } \\
\text { n (\%) }\end{array}$ & $\begin{array}{c}\text { No } \\
\mathrm{n}(\%)\end{array}$ & $\begin{array}{c}\text { Do not know } \\
\mathrm{n}(\%)\end{array}$ \\
\hline Heard about epilepsy & $134(100)$ & 0 & 0 \\
\hline Epilepsy is a contagious disease & $2(1.5)$ & $132(98.5)$ & 0 \\
\hline Epilepsy is a brain chronic disease that can not be cured or controlled & $18(13.4)$ & $105(78.4)$ & $11(8.2)$ \\
\hline Seizure occurs when an abnormal electric discharge happen in the brain & $81(60.4)$ & $10(7.46)$ & $43(32.1)$ \\
\hline All individuals that have seizure present epilepsy & $6(4.5)$ & $113(84.3)$ & $15(11.2)$ \\
\hline People with epilepsy have difficulties of learning & $7(5.2)$ & $100(74.6)$ & $27(20.1)$ \\
\hline The ratio of individuals with epilepsy in Brazil is $2 \%$ & $12(9.0)$ & $5(3.7)$ & $117(87.3)$ \\
\hline People with epilepsy should study in a special classroom & $2(1.5)$ & $124(92.5)$ & $8(6.0)$ \\
\hline Fear to live with a person with epilepsy & $1(0.8)$ & $130(97.0)$ & $3(2.2)$ \\
\hline Would have a partner with epilepsy & $97(72.4)$ & $30(22.4)$ & $7(5.2)$ \\
\hline
\end{tabular}

Table 2. Previous professional experience with epilepsy.

\begin{tabular}{lccc}
\hline Question & Yes & No & Do not know \\
Have seen a seizure & $\mathbf{n}(\%)$ & $\mathbf{n}(\%)$ & 0 \\
Have a friend or relative with epilepsy & $82(61.2)$ & $52(38.8)$ & $4(3.0)$ \\
Have had a student with epilepsy & $37(27.6)$ & $93(69.4)$ & $6(4.5)$ \\
Helped someone during a seizures & $19(14.2)$ & $109(81.3)$ & 0 \\
Access to any kind of information about epilepsy & $39(29.1)$ & $95(70.9)$ & 0 \\
\hline
\end{tabular}

$\mathrm{n}=113$ ) answered that persons having convulsions will not necessarily present epilepsy. Five percent $(n=7)$ believe that people with epilepsy have difficulties of learning. Genetic $(58.2 \%, n=78)$, cerebral disease $(44 \%, n=59)$, trauma (24.6\%, $\mathrm{n}=33)$, malformation $(17.9 \%, \mathrm{n}=24)$ tumor $(10.4 \%$, $\mathrm{n}=14)$ and infection $(4.5 \%, \mathrm{n}=6)$ were the most referred causes of epilepsy. Twenty-one professionals (15.6\%) answered that the etiology of epilepsy is not known. Surprisingly, one person referred that epilepsy could be related to supernatural causes and two persons that people with epilepsy should study in a special classroom. Ninety-seven percent $(n=130)$ have no fear to live with a person with epilepsy and $72.4 \%(\mathrm{n}=97)$ would not mind to have a partner with epilepsy (Table 1).

The second part of the questionnaire was concerned to previous professional experience with epilepsy. In these lines, $61.2 \%(n=82)$ of physical educators have seen a seizure, $27.6 \%(n=37)$ have a friend or relative with epilepsy and $14.2 \%(n=19)$ have had a student with epilepsy. Fiftythree percent $(n=71)$ of them had access to any kind of information (i.e., books, leaflets, papers, etc.) and 29.1\% $(n=39)$ helped someone during seizures (Table 2).

\section{DISCUSSION}

The investigation of physical educators' attitude and knowledge about epilepsy has been extremely limited.
This evaluation is of great importance since attitudes toward people with epilepsy should be influenced by the degree of the professional knowledge about this subject ${ }^{22}$. To our knowledge, this is the first study to evaluate physical educators' general knowledge about epilepsy.

Although the favourable effect of physical fitness on general health is unquestionable, people with epilepsy are often excluded from participation of physical activity. This reluctance to allow people with epilepsy to participate in sports stems from both physicians and overprotective parents $\mathrm{s}^{23}$. Generally, these professionals do not receive any formal instruction on epilepsy during their graduate program. Some important points concerning persons with epilepsy habits should be highlighted. Steinhoff et al. ${ }^{6}$, in their study concluded that people with epilepsy suffer from a considerable lack of physical fitness that might have an important impact on their general health and quality of life. In fact, several studies have showed a low degree of participation in physical activities among people with epilepsy $y^{3,5,8}$. For instance, in a study of patients with epilepsy in Norway only 23\% participated in organized physical activity ${ }^{8}$. We should also consider whether these patient samples may or not be directly applicable to developing countries. Surprisingly, a research carried out in Brazil by Arida et al. ${ }^{10}$ reported that the majority of people with epilepsy were engaged in 
physical activities and believed that sports did not precipitate seizures.

Some topics concerning general knowledge about epilepsy such as definition of a seizure or convulsion were suitably answered by most of the responders; however, physical educators were not confident regarding the different causes of epilepsy and its incidence. The findings about education and learning differed among subjects. Only a small number of physical educators admitted that people with epilepsy might have special treatment at school such as studying in a special classroom and only a few believe that epilepsy do interfere in learning. Accordingly, in a Thailand study, $15 \%$ of school teachers were in favor to place children with epilepsy in a special classroom $^{24}$. Conversely, the majority of teachers in another survey conducted in Zimbabwe were in agreement to teach children with epilepsy ${ }^{25}$. The majority of teachers were familiar with epilepsy although many of them complained about the extent of their knowledge concerning this disease $\mathrm{e}^{22}$. In this regard, our findings are in agreement with a study developed by Thompson and Duncan ${ }^{26}$ who investigated the relation between seizure-related variables and cognitive change in patients with severe intractable epilepsy. They demonstrated that seizures may have a direct adverse effect on cognition but a good seizure control even after years of intractability may produce a beneficial impact on cognitive prognosis. Conversely, another report showed that $15 \%$ of school teachers were in favor to place children with epilepsy in a special classroom ${ }^{24}$. This preference may be consequence from fear of having to deal with a seizure and/or due to the degree of knowledge of how management with this condition ${ }^{22}$.

Attitudes toward epilepsy have changed over the years. In 1979, the American Institute of Public Opinion collected information concerning knowledge of epilepsy of the adult population throughout the United States for a period of 30 years. Changes in opinion (employment, education, insanity, cause of epilepsy, social attitude) as reflected in polls of 5 year intervals increased during this period $^{27}$. In addition, knowledge and attitudes toward epilepsy among teachers in a Brazilian study showed that although almost all teachers had heard about epilepsy, the knowledge on clinical characteristics and initial procedures to attend a person with epilepsy during a seizure was unsatisfactory ${ }^{28}$.

Questions concerning to professional experience in epilepsy also demonstrate lack of information among physical educators. Almost $40 \%$ of the professionals have never observed a seizure. The question whether they had a friend or relative with epilepsy complements the previous question showing that $22.4 \%$ of responders did not go through a person with epilepsy. In addition, we were expecting that physical educators would get any kind of in- formation about epilepsy during their graduate program, conversely, $47 \%$ of them have never heard about it.

Finally, it is important to note the limitations of questionnaire studies and problems with attitude surveys have been previously highlighted ${ }^{29}$. Accordingly, this investigation may also provide a guide for more extensive studies. In conclusion, the findings of the present study put on view the insufficient knowledge among health professionals and sport instructors about the knowledge of physical exercise for people with epilepsy.

Campaigns promoting greater knowledge about epilepsy to non-medical professionals should be launched. Many of the gym instructors are not really familiar with general information and initial procedures to employ when attending a person during a seizure. With specific instruction among them, a more tolerant attitude towards epilepsy can be expected in the hope of achieving the objectives of the "Out of the Shadow" World campaign.

\section{REFERENCES}

1. Sander JW. The epidemiology of epilepsy revisited. Curr Opin Neurol 2003; 16:165-170.

2. Pollock ML, Franklin BA, Balady GJ, et al. AHA Science Advisory. Resistance exercise in individuals with and without cardiovascular disease: benefits, rationale, safety, and prescription: an advisory from the Committee on Exercise, Rehabilitation, and Prevention, Council on Clinical Cardiology, American Heart Association; Position paper endorsed by the American College of Sports Medicine. Circulation 2000;101:828-833.

3. Nakken $\mathrm{KO}$, Bjorholt PG, Johannessen SI, Loyning T, Lind E. Effect of physical training on aerobic capacity, seizure occurrence, and serum level of antiepileptic drugs in adults with epilepsy. Epilepsia 1990;31:88-94.

4. Arida RM, Cavalheiro EA, da Silva AC, Scorza FA. Physical activity and epilepsy: proven and predicted benefits. Sports Med 2008;38:607-615.

5. Roth DL, Goode KT, Williams VL, Faught E. Physical exercise, stressful life experience, and depression in adults with epilepsy. Epilepsia 1994;35:1248-1255.

6. Steinhoff BJ, Neusüss K, Thegeder H, Reimers CD. Leisure time activity and physical fitness in patients with epilepsy. Epilepsia 1996;37:1221-1227.

7. Wong J, Wirrell E. Physical activity in children/teens with epilepsy compared with that in their siblings without epilepsy. Epilepsia 2006;47:631-639.

8. Bjorholt PG, Nakken KO, Rohme K, Hansen H. Leisure time habits and physical fitness in adults with epilepsy. Epilepsia 1990;31:83-87.

9. Nakken KO. Physical exercise in outpatients with epilepsy. Epilepsia 1999 40:643-651.

10. Arida RM, Scorza FA, Albuquerque M, Cysneiros RM, Oliveira RJ, Cavalheiro EA. Evaluation of physical exercise habits in Brazilian patients with epilepsy. Epilepsy Behav 2003;4:507-510.

11. Gotze W, Kubicki St, Munter M, Teichmann J. Effect of physical exercise on seizure threshold. Dis Nerv Syst 1967;28:664-667.

12. Eriksen HR, Bjorn E, Gronningsaeter H, Nakken KO, Loyning Y, Ursin H. Physical exercise in women with intractable epilepsy. Epilepsia 1994;35:1256-1264.

13. Arida RM, Jesus Vieira A, Cavalheiro EA. Effect of physical exercise on kindling development. Epilepsy Res 1998;30:127-132.

14. Arida RM, Scorza FA, Santos NF, Peres CA, Cavalheiro EA. Effect of physical exercise on seizure occurrence in a model of temporal lobe epilepsy in rats. Epilepsy Res 1999;37:45-52

15. Arida RM, Scorza CA, Scorza FA, Gomes da Silva S, Graça Naffah-Mazzacoratti $M$, Cavalheiro EA. Effects of different types of physical exercise on the staining of parvalbumin-positive neurons in the hippocampal formation of rats with epilepsy. Prog Neuropsychopharmacol Biol Psychiatry 2007;31:814-822.

16. Arida RM, Scorza FA, Terra VC, Cysneiros RM, Cavalheiro EA. Physical exercise in rats with epilepsy is protective against seizures. Arq Neuropsiquiatr 2009; 67:1013-1016.

17. Kuijer A. Epilepsy and exercise, electroencephalographical and biochemical studies. In: Wada JA, Penry JK (Eds). Advances in epileptology: the $10^{\text {th }}$ Epilepsy International Symposium, New York: Raven Press, 1980:543. 
18. Cordova F. Epilepsy and sport. Australian Family Physician 1993;22:558-562.

19. Camilo F, Scorza FA, Albuquerque M, Vancini RL, Cavalheiro EA, Arida RM. Evaluation of intense physical effort in subjects with temporal lobe epilepsy. Arq Neuropsiquiatr 2009;67:1007-1012.

20. Arida RM, Fernandes MJ, Scorza FA, Preti SC, Cavalheiro EA. Physical training does not influence interictal LCMRglu in pilocarpine-treated rats with epilepsy. Physiol Behav 2003;79:789-794.

21. Haskell WL, Lee IM, Pate RR, et al. Physical activity and public health: updated recommendation for adults from the American College of Sports Medicine and the American Heart Association. Med Sci Sports Exerc 2007;39:1423-1434.

22. Millogo A, Siranyan AS. Knowledge of epilepsy and attitudes towards the condition among schoolteachers in Bobo-Dioulasso (Burkina Faso). Epileptic Disord 2004;6:21-26.

23. Dubow JS, Kelly JP. Epilepsy in sports and recreation. Sports Med 2003;33: 499-516.
24. Kankirawatana P. Epilepsy awareness among school teachers in Thailand. Epilepsia 1999:40:497-501.

25. Mielke J, Adamolekun B, Ball D, Mundanda T. Knowledge and attitudes of teachers towards epilepsy in Zimbabwe. Acta Neurol Scand 1997;96: 133-137.

26. Thompson PJ, Duncan JS. Cognitive decline in severe intractable epilepsy. Epilepsia 2005;46:1780-1787.

27. Caveness WF, Gallup GH Jr. A survey of public attitudes toward epilepsy in 1979 with an indication of trends over the past thirty years. Epilepsia 1980;21: 509-518.

28. Dantas FG, Cariri GA, Cariri GA, Ribeiro Filho AR. Knowledge and attitudes toward epilepsy among primary, secondary and tertiary level teachers. Arq Neuropsiquiatr 2001;59:712-716.

29. Davies D, Scambler G. Attitudes towards epilepsy in general practice. Int J Social Psychiatry 1988;34:5-12. 